\title{
The Peculiarities of the Social Security Systems (Indirect State Administration)
}

\author{
Dieter Schimanke
}

1 The Welfare State, Its Programmes (Laws) and Entrenchment in Administrative Federalism

Germany is a welfare state. Over the years, it has been shaped by different directions and waves of development. The welfare system is a highly differentiated social system in terms of benefits and therefore target groups, institutions and financing. The welfare state has constitutional status (Article 20 (1) of the Basic Law).

Social policy is characterised by three principles: the public welfare principle, the compensation principle and the insurance principle. Social assistance is the expression of the first principle that entails benefits in situations of personal need, where the individual is not able to care for his or her personal needs without assistance. These are financed through tax revenue. The compensation principle is an expression of the solidarity of the public community as a whole. The benefits are also financed through tax

D. Schimanke $(\bowtie)$

Ministry of Labour, Women, Health, Social Affairs of the German Land Saxony-Anhalt, Magdeburg, Germany

(C) The Author(s) 2021

S. Kuhlmann et al. (eds.), Public Administration in Germany, Governance and Public Management, https://doi.org/10.1007/978-3-030-53697-8_7 
revenue. These include, for example, a benefit to the community with respect to the upbringing of children (child benefit-Kindergeld) or sacrifices for the community (e.g. victims of war, violent crimes and vaccination injuries). The third principle, the insurance principle, has the biggest influence over the German welfare state. It finds expression in the five branches of the social insurance system. These have their roots in the early labour movement and in the legislation introduced during the time of Chancellor Bismarck, namely health insurance (1883), occupational accident insurance (1884) and pension insurance (1889). The structure of the organisation and administration as well as the financing were already contained in this legislation. Financing is effected through contributions to the social insurance, which are calculated based on the wages by applying a nonconstant percentage over time (either with contributions from both the employee and employer or, in the case of occupational accident insurance, from the employer ${ }^{1}$ ). With regard to pension insurance, a considerable part of the financing comes from tax revenue or is subsidized by the federal budget (over the years this has increased to approximately $€ 100$ billion or $30 \%$ of pension insurance expenditure in 2019; one reason for financing from tax revenues is that services not related to employment but to social policy are included, for example pension benefits for child-rearing periods). In respect of unemployment insurance, the federal government provides liquidity assistance in the form of loans.

The Federal Republic of Germany, as established under the Basic Law of 1949, has continued to build on the historical bases of social policy of the later years of the nineteenth century and the early years of the twentieth century (e.g. unemployment insurance was added in 1927). In recent decades, the state has further developed the substance of the social security systems (e.g. by introducing far-reaching pension reforms, expanding the unemployment insurance system to an active labour market policy and introducing in 1995 long-term care insurance, the so-called fifth pillar of the social insurance system). The various areas of social policy and associated functions are allocated to the three levels of the German administrative system (federal, state and local government level). Alongside there are also independent institutions dealing with social insurance covering the risks of illness, long-term care, old-age (pensions), unemployment and occupational accidents.

All three levels of the administrative system, therefore, have a responsibility in relation to the welfare state and its various programmes (laws). The central level is dominant in the area of legislation, especially on 
Table 7.1 Contents of the 12 books of the Social Code

\begin{tabular}{ll}
\hline Book number & Title and content \\
\hline Book I & Universal principles and fundamental principles \\
Book II & Basic income support for job seekers \\
Book III & Promotion of employment \\
Book IV & Common regulations for the social insurance systems \\
Book V & Statutory health insurance \\
Book VI & Statutory pension insurance \\
Book VII & Statutory occupational accident insurance \\
Book VIII & Child and youth welfare \\
Book IX & Rehabilitation and participation of disabled persons \\
Book X & Administrative procedures and protection of social data \\
Book XI & Social long-term care insurance \\
Book XII & Social assistance and services \\
\hline
\end{tabular}

account of its role in the codification of social law in the form of Social Codes (Sozialgesetzbücher) and in the legal supervision of most of the social insurance institutions. To date, there are 12 Books of the Social Code (Sozialgesetzbuch-SGB) covering the aspects shown in Table 7.1.

Book X of the Social Code sets out the basic principles of the administrative procedures. It not only follows the principles of the Administrative Procedures Act (Verwaltungsverfahrensgesetz) (cf. Chap. 11), but also contains special rules applicable to the social administrations.

In addition, there is further federal legislation pertaining to benefits, inter alia, for the target groups of trainees, children, victims of war and other so-called sacrificial victims (Aufopferungen, e.g. people injured by compulsory vaccination), and recipients of housing benefits. The recently introduced basic income support is codified in two of the social codes mentioned above. The benefits for job seekers are contained in SGB II, and for pensioners and persons unable to work in SGB XII. Basic income support is, at the same time, however, a prime example of administrative federalism: the municipalities execute federal law in respect of pensioners as delegated matters (übertragene Angelegenheiten) and in respect of persons with diminished earning capacity as mandated matters (Auftragsangelegenbeiten) (with the result that the federal government has a direct right of control over the latter). In respect of job seekers, a form of mixed administration between the federal administration (Federal Employment Agency) and the municipalities has been created, which is 
problematic from a constitutional point of view. This situation has been 'healed' by an amendment to the constitution (Article 9le of the Basic Law), but remains an exception in administrative federalism, which is shaped by the principle of having a clear assignment of responsibilities.

Within the administrative system of Germany, the implementation of social policy is broadly in accordance with the above-mentioned three principles in light of the following attributes: the public welfare principle has its main focus on local government; the compensation principle is a distinctive feature of the state administration; and the insurance principle is located mainly at the federal level.

\section{Areas of Social Benefits and Their Allocation Within the Administrative System of Germany}

The individual areas of social policy and their related expenses are outlined in the social budget (cf. BMAS 2019b). These relate to non-cash benefits (e.g. medicine, vehicle, guide dog) and cash benefits (e.g. child benefit) as well as personal support benefits (e.g. care at home). ${ }^{2}$

Personnel expenditure pertaining to social policy is spread across all public budgets based on the division of responsibilities. The charts pertaining to activities in social administration show a total of 705,600 fulltime equivalent (FTE) jobs (including social security providers). This represents $16.7 \%$ of all FTE in public administration. As can be gleaned from the summary table of the distribution between the three levels of federal administrative system and the social insurances (Table 7.2), the focus of executory social administration lies with the municipalities and counties (local administration) on the one hand and the social security institutions and agencies on the other.

Table 7.2 Personnel in administrations on social affairs

FTE (full-time equivalent)

\begin{tabular}{lr}
\hline Federal & 7225 \\
States & 29,180 \\
Local level & 342,455 \\
Social insurance systems & 326,740 \\
Total & 705,600 \\
\hline
\end{tabular}

Source: Statistisches Bundesamt (2019) Finanzen und Steuern. Personal des öffentlichen Dienstes 2018. Fachserie 14, Reihe 6, p. 53 
Table 7.3 Personnel of social security providers ('indirect public administration', 'near governmental units', Parafisci)

\begin{tabular}{ll}
\hline Function & FTE (full-time equivalent) \\
\hline Health insurance & 126,680 \\
Occupational accident insurance & 22,705 \\
Pension insurance & 53,445 \\
Other organisations & 7950 (with rounding \\
& differences) \\
Union of miners' insurance and social insurance for the & 14,740 \\
agricultural sector & \\
Federal Employment Agency & 101,225 \\
Total & $\mathbf{3 2 6 , 7 4 0}$ \\
\hline
\end{tabular}

Note: The numbers are taken from this publication of the Federal Agency of Statistics. For the category 'Other organisations' the following explanation is given: sums might not fit due to rounding differences caused by security reasons

Source: Statistisches Bundesamt (2019) Finanzen und Steuern. Personal des öffentlichen Dienstes 2018. Fachserie 14, Reihe 6, p. 74

The social security providers are independent public institutions and agencies alongside the administrations at the federal, state and local levels. They employ their own personnel, which is shown separately in the statistics (Tables 7.2 and 7.3). The budgets are separate and are also different to the budgets of the three territorial authorities (Gebietskörperschaften). Consequently, the social security providers are also labelled 'indirect public administration' (mittelbare Staatsverwaltung) or 'near governmental units' (Parafisci). Their independence is evidenced by their special legal status (corporate body subject to public law (Körperschaft des öffentlichen Rechts), Section 29 (1) SGB IV). Corporate body means that they have members (the insured individuals and the employers) and legal capacity, which means that they can enforce their rights through the courts (e.g. against measures of government supervision) and can be sued themselves (e.g. by the insured in respect of benefits). The limits to state supervision and control (see part 3 below) are also interconnected with this semi-autonomous status.

Compared to an expenditure budget of $€ 634.5$ billion (Table 7.4: total of sections 1 and 2), the number of contingent personnel in the social insurance systems amounting to $326,740 \mathrm{FTE}$, or $7.9 \%$ of all persons employed in the public service, is relatively small. This is because the different institutions of the social security systems mainly provide financial transfers as routine cases of mass administration. The share of the expenditure budgets of the social insurance systems in relation to the 


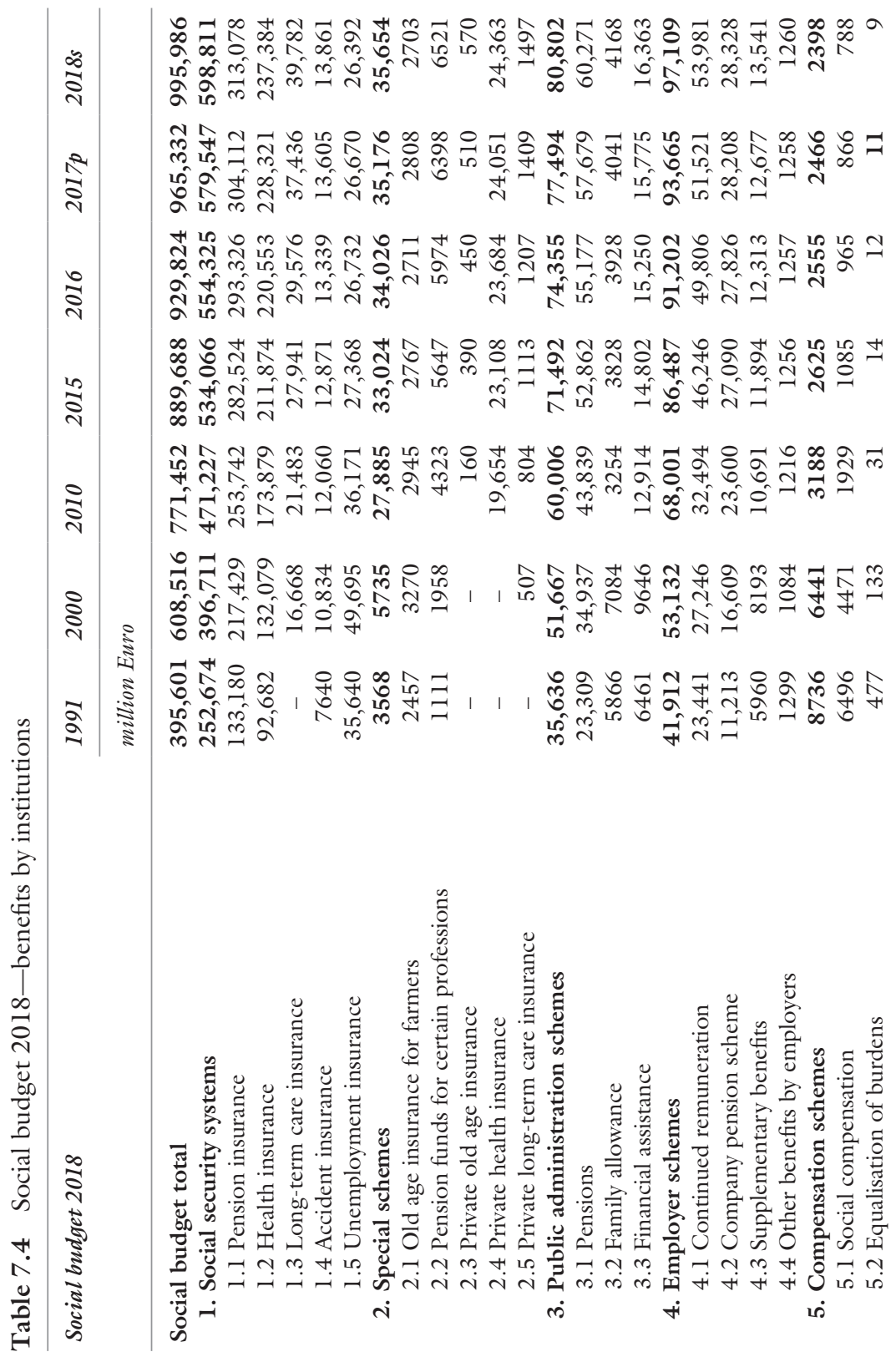




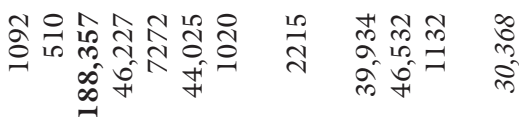

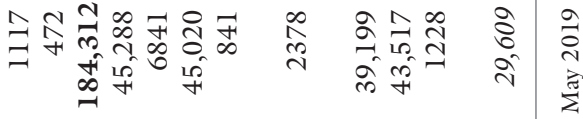

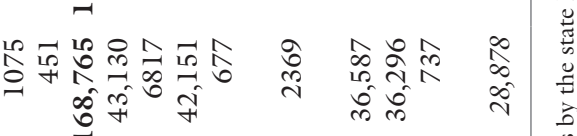

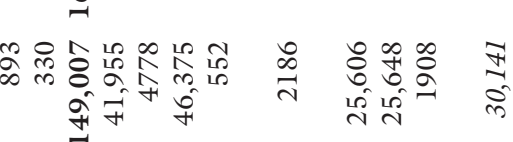

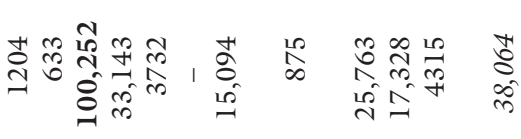

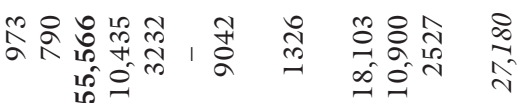

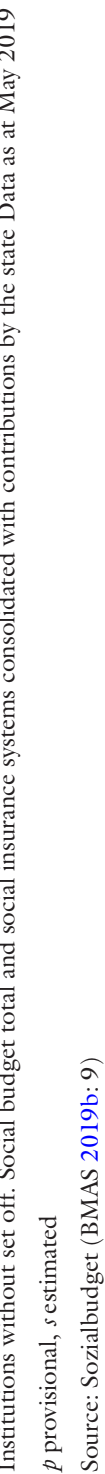


expenditure of all public budgets is rather high with $43.3 \%$ (see Chap. 14, Table 12.1: $€ 648$ billion out of $€ 1429$ billion).

If one takes the extent of the individual benefits and the budgets as a basis, the social insurances are dominant in the policy and administrative areas of social benefits. The expenditure of the social insurances amounts to approximately two-thirds of the entire social budget (cf. Table 7.4).

The social budget share of gross domestic product (GDP) is $29.4 \%$ (of which the social insurance systems, with a share of $17.7 \%$ of GDP, cover approximately two-thirds; cf. Sozialbudget 2018: 12). The social budget covers about $45 \%$ of the expenditure of all public budgets. The funding comprises of $34.5 \%$ social security contributions by the employers, $30.9 \%$ social security contributions by the insured and $33 \%$ subsidies by the state (Fig. 7.1).

The Social Budget according to areas of coverage in 2018: Shares in the total expenditures including contributions by the State

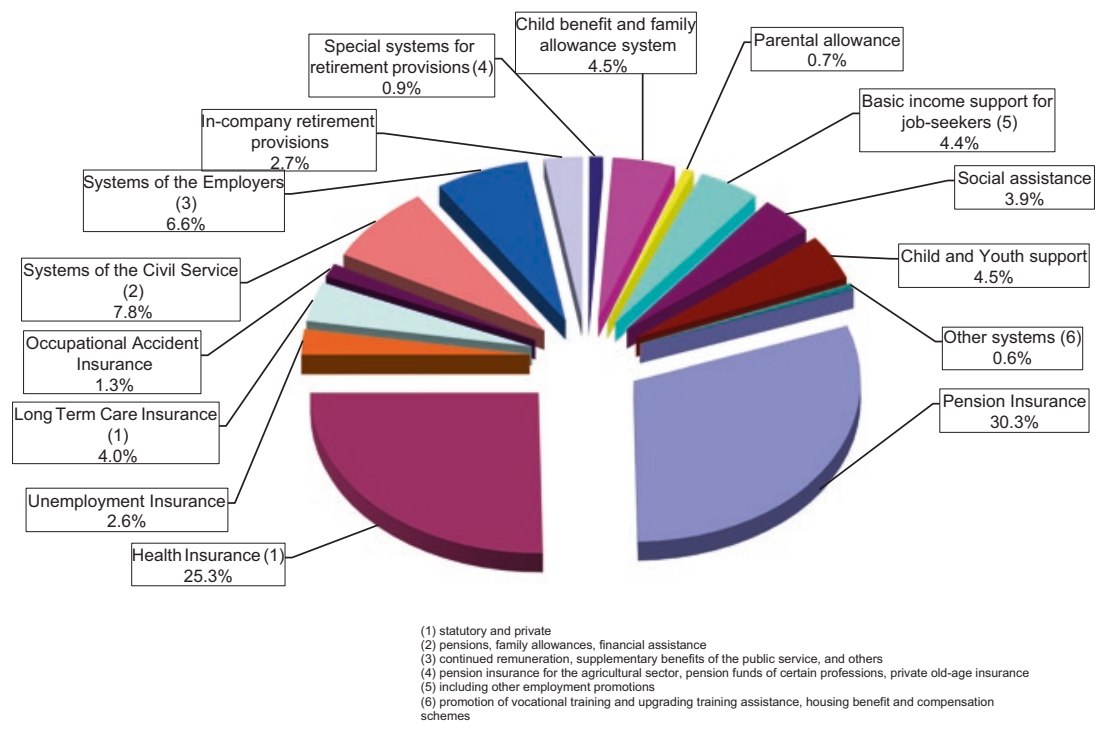

Fig. 7.1 The social budget according to the branches of social security (including the five branches of the social security system: illness, occupational accident, personal care, unemployment, pension). Pension insurance: $30.3 \%$, health insurance: $25.3 \%$, long-term care insurance: $4.0 \%$, systems of civil service: $7.8 \%$, 


\section{The Special Status of the Social Security Systems and Their Relationship to the General Administrative System}

\subsection{The Legal Bases of the Public Institutions in the Social Security Systems}

The social security institutions and agencies have been established as independent bodies alongside general public administration. They are granted by law the status of public corporate body with legal capacity and the right to self-administration (rechtsfähige öffentliche Körperschaft mit Selbstverwaltungscharakter) (Section 29 SGB IV). The regulatory framework for organisation, finances, human resource management, decisiontaking, etc. is based on federal laws, on the one hand, (mainly on SGB IV) and ordinances, which are passed by the committees of the social security institutions and agencies, on the other. The supervisory authority (Aufsichtsbehörde) has to either approve these ordinances (cf. Section 195 SGB V) or raise objections if they are inconsistent with the applicable laws. The representative committee (governing board-Vertreterversammlung) is elected every six years by the members (i.e. usually the insured individuals and the employers). An exception is the unemployment insurance. In this regard, the Federal Ministry for Labour and Social Affairs appoints the members of the governing board pursuant to nominations from the employers' associations and trade unions as well as from the federal government, states and municipalities. The representative committee

Fig. 7.1 in-company retirement provisions: $2.7 \%$, child benefit and family allowance system: $4.5 \%$, basic income support for job seekers: $4.4 \%$, child and youth support: $4.5 \%$, unemployment insurance: $2.6 \%$, occupational accident insurance: $1.3 \%$, systems of the employers: $6.6 \%$, special systems for retirement provisions: $0.9 \%$, parental allowance: $0.7 \%$, social assistance: $3.9 \%$, other systems: $0.6 \%$. (1) Statutory and private, (2) pensions, family allowances, financial assistance, (3) continued remuneration, supplementary benefits of the public service and others, (4) pension insurance for the agricultural sector, pension funds of certain professions, private old-age insurance, (5) including other employment promotions, (6) promotion of vocational training and upgrading training assistance, housing benefit and compensation schemes. (Source: Sozialbudget 2018 (BMAS 2019b): 6) 
(governing board) elects the executive board. The executive board does not need to be confirmed by a public authority (with the exception that the executive board of the Federal Employment Agency (Verwaltungsrat) is appointed by the federal government, based on the recommendation of the governing board).

The bodies of the social security systems draw up yearly budgets. In this regard, the budget principles are similar to those set out in the federal budget code (budget code; see Chap. 14) and in the social code (Section $67 \mathrm{ff}$. SGB IV). The supervisory authority may request the budget and can object to it if it is in contravention of legal requirements. The unemployment insurance and the miners' pension insurance budgets require the approval of the responsible federal ministry since the federal government is liable as guarantor. In respect of the general pension insurance at the federal level, the liquidity assistance provided by the federal government only leads to an obligation to advise on the budget. An approval by the federal government is not required.

The way elections are structured, the creation of programmes (by way of ordinances) and the restrictive rules in respect of the budgets differ greatly from the scope of autonomy characteristic of local self-government with direct elections by the citizens and broad areas of autonomous decision-making (see Chap. 9). This is because almost all the benefits provided by the social insurances are regulated by federal laws and manifest as legal rights of the insured (Section 38 SGB I) — with only very limited discretion on the part of self-government (cf. Reit 2015). The institutions are formed by representatives elected by employers and insured individuals. In this regard, this form of self-government can also be characterised as a special type of self-government with autonomous legitimation and restricted scope for decision-making (cf. Schimanke 2001). Their origin lies in the pre-democratic time of the Bismarck era and aimed at promoting social stability by involving employees and employers directly in the internal decision-making structures. The social security systems are now incorporated into the fundamental principles and the constitutional framework of the Basic Law (Article 74 (1), number 12; Article 87 [2]).

\subsection{Oversight of the Social Security Systems}

The social security institutions and agencies are independent bodies yet part of public administration ('indirect public administration', 'near governmental units'). They are bound by the laws and are required to 
implement them. The federal and state governments have to ensure that the social security systems implement legislation and work within the legal framework. Government oversight extends to ensuring that legislation and other laws are observed (Section 87 (1) SGB IV and Section 393 (1) SGB III) and, thus, is limited to legal supervision (cf. Chap. 6). However, in exceptional cases related to the so-called delegated tasks (übertragene Aufgaben), the oversight extends beyond examining the legality of measures to expert supervision (Fachaufsicht), which means that in these cases administrative expediency can also be evaluated. Examples in this regard are prevention tasks for occupational accident insurance or the family benefits offices (Familienkassen) of the Federal Employment Agency (execution of the Law on Child Benefits).

The structure and responsibilities of the supervisory authorities reflect the features of administrative federalism (cf. Section 90 SGB IV). As a rule, the states have supervisory authority over the social security systems, which is limited to the area of one state (up to 3 states when they agree on supervision, cf. Article 87 (2), sentence 2 of the Basic Law). This mainly applies to regional health insurers, occupational accident insurers and the regional authorities of pension insurance. Usually, the state ministries of social affairs carry out the supervision; some states have tasked their own government agencies with this. In the vast majority of cases, the oversight function is vested in the Federal Government and is carried out either by the ministry responsible (usually the Federal Ministry for Labour and Social Affairs) or its subordinate, the Federal Office for Social Security. The supervisory authorities meet regularly to exchange experiences (Section 90 paragraph 4 SGB IV). This practical approach has brought about the expansion of administrative federalism to very intensive networks.

The legal supervision by government agencies is the expression of a legitimate interest of the state and its responsibility to ensure that institutions and social security benefits comply with legal requirements (cf. Beschorner 2015; Kahl 2013: 514). In this regard, the independent status as a corporate body subject to public law with right to self-government (Körperschaft des öffentlichen Rechts mit Selbstverwaltung) has to be taken into account. It follows that legal supervision, when choosing supervisory means, has to be mindful of the leeway afforded by legislation (especially in form of the so-called scope for appreciation (unbestimmter Rechtsbegriff) and discretion (see Chap. 12); internal organisation and budgets). The principle of the least invasive interference applies—as codified in Section 
89 SGB IV-ultimately an expression of the rule of law principle (Ausdruck des Rechtsstaatsprinzips) (see Chap. 2). The Federal Social Court upholds that a decision, which is justifiable, should not be objected to. Oversight can be pre-emptive or repressive. Consultation applies in the first place. Once a violation of law becomes evident, an objection will be raised with the requirement to remedy such violation within a certain period of time. It is only then that an administrative decision obligating compliance (Verpflichtungsbescheid) is issued against the social security system in question. This administrative decision constitutes an exercise of discretion by the oversight authority. The latter can uphold the decision (e.g. declare invalid an election or budget) as soon as it becomes legally binding. Since the social security systems are corporate bodies with legal capacity, they can take legal action before the social courts against the administrative decisions of the legal supervision.

\section{LESSONS LEARNED}

It may be advisable to develop a policy field with broader scope in the structured (federative) administrative system that is independent or semiautonomous of the constitutional point of view and thus unburdens the state and the general administration. General public administration will be unburdened by operational functions. The social security institutions and agencies have a vested right to decide for themselves on ordinances, personnel and budgets (so-called functional self-government). The state, via legal supervision, has the task and opportunity to monitor compliance with legal requirements. The system of semi-independent authorities responsible for social security benefits does not insignificantly contribute to the fact that the institutions of the public sector are accepted and legitimised.

\section{Notes}

1. Employers have the significant advantage that occupational accident insurances (mainly named 'Berufsgenossenschaft'/employers mutual insurance association) assume the liability of the employers in cases of occupational accidents. Moreover, for several decades now the occupational accident insurances also cover the claims of voluntary services.

2. A detailed survey is published by the Federal Ministry of Labour and Social Affairs: BMAS 2019a. https://www.bmas.de/SharedDocs/Downloads/ DE/PDF-Publikationen/a998-social-security-at-a-glance-total-summary. pdf?_blob=publicationFile $\& v=9$. 


\section{REFERENCES}

Beschorner, J. (2015). Staatsaufsicht über Sozialversicherungsträger. In L. Mülheims, K. Hummel, S. Peters-Lange, E. Toepler, \& I. Schumann (Eds.), Handbuch Sozialversicherungswissenschaft (pp. 777-798). Wiesbaden: Springer. Federal Ministry of Labour and Social Affairs (BMAS) (Ed.). (2019a). Devision KS 3. Social Security at a Glance 2019. Bonn.

Federal Ministry of Labour and Social Affairs (BMAS) (Ed.). (2019b). Sozialbudget 2018. Bonn. Retrieved from https://www.bmas.de/SharedDocs/Downloads/ DE/PDF-Publikationen/a230-18-sozialbudget-2018.pdf?_-_blob= publicationFile \&v=2 .

Kahl, W. (2013). Begriff, Funktionen und Konzepte von Kontrolle. In W. Hoffmann-Riem, E. Schmidt-Aßmann, \& A. Voßkuhle (Eds.), Grundlagen des Verwaltungsrechts (Vol. III, 2nd ed., pp. 459-591). München: Beck.

Reit, N.-A. (2015). Rechtliche Determinanten der Selbstverwaltung in der Sozialversicherung. In L. Mülheims, K. Hummel, S. Peters-Lange, E. Toepler, \& I. Schumann (Eds.), Handbuch Sozialversicherungswissenschaft (pp. 763-776). Wiesbaden: Springer.

Schimanke, D. (2001). Self-Administration Outside Local Government-With Special Reference to Self-Administration in the Field of Social Insurance. In K. König \& H. Siedentopf (Eds.), Public Administration in Germany (pp. 215-226). Baden-Baden: Nomos.

Open Access This chapter is licensed under the terms of the Creative Commons Attribution 4.0 International License (http://creativecommons.org/licenses/ by $/ 4.0 /$ ), which permits use, sharing, adaptation, distribution and reproduction in any medium or format, as long as you give appropriate credit to the original author(s) and the source, provide a link to the Creative Commons licence and indicate if changes were made.

The images or other third party material in this chapter are included in the chapter's Creative Commons licence, unless indicated otherwise in a credit line to the material. If material is not included in the chapter's Creative Commons licence and your intended use is not permitted by statutory regulation or exceeds the permitted use, you will need to obtain permission directly from the copyright holder.

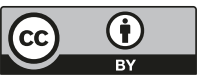

